Article

\title{
Managerial Perceptions of Firms' Corporate Sustainability Strategies: Insights from Croatia
}

\author{
Richard Nyuur ${ }^{1, *(\mathbb{D})}$, Ružica Brečić ${ }^{2}\left(\mathbb{D}\right.$ and Patrick Murphy ${ }^{3}$ \\ 1 Newcastle Business School, Northumbria University, Newcastle upon Tyne NE1 8ST, UK \\ 2 Department of Marketing, Faculty of Economics and Business, University of Zagreb, 10000 Zagreb, Croatia; \\ rbrecic@efzg.hr \\ 3 Department of Marketing, Mendoza College of Business, University of Notre Dame, Notre Dame, \\ IN 46556-5646, USA; Patrick.E.Murphy.72@nd.edu \\ * Correspondence: richard.nyuur@northumbria.ac.uk; Tel.: +44-191-227-3336
}

Received: 10 August 2019; Accepted: 11 December 2019; Published: 27 December 2019

\begin{abstract}
Although corporate social responsibility (CSR) has gained increasing academic attention, we lack a solid understanding of how managerial perceptions underpin firms' sustainability practices. This study interprets and sheds light on managers' perceptions of sustainability activities under various stakeholder domains in Croatia through a multi-theoretical approach. Using 21 semi-structured interviews with managers, the study reveals that sustainability activities in the research context tend to focus more on environmental issues and customer service, as well as employees and supplier domains. The study further establishes three distinct levels of sustainability commitments by firms. These stages include sustainability as a minimal response, corporate culture-driven, and committed response. These findings, as a whole, are insightful and enable us to advance research on sustainability by elucidating how managerial perceptions underpin firms' strategic sustainability activities. The contributions to theory and practice are also discussed.
\end{abstract}

Keywords: sustainability; corporate responsibility; managerial perceptions; Eastern Europe; Croatia; stakeholder domains

\section{Introduction}

The increasing social and ecological challenges confronting the global community have been attributed to the lack of attention on sustainability practices in the business environment by both academics and managers alike [1,2]. Business organizations are often accused of being the primary contributors to unsustainability in terms of environmental and social impact [3]. This has contributed to various stakeholders demanding for organizations to pay more attention to sustainability activities rather than to their short-term economic returns [1]. Academic research has thrived at the same time, and whilst most of the theoretical, and empirical work has yielded important insights, there is little understanding of the role of managerial perception of sustainability activities in shaping corporate sustainability practices $[1,4,5]$. Accordingly, managers' perception of the nature and impact of sustainability in organizations can differ in the business world [6].

However, there has been little research on how the perceptions of managers might influence their attitudes and behaviors towards sustainability in their organizations [7]. Moreover, the limited existing studies on managerial perceptions are characterized by inaccurate objective measures leading to unsatisfactory results on managerial perceptions [4]. The perception of managers is an arguably significant determinant of companies' approaches to sustainability since corporate sustainability management is embedded in the context of economic competitiveness and the societal business environment $[5,8]$. Despite this, existing studies have not explicitly examined managerial perceptions 
of the nature, relative importance, and impact of sustainability issues within organizations. The main purpose of this study is, therefore, to help close this research gap and advance our knowledge of corporate sustainability with regards to managerial perception. The research question, therefore, is how do managers perceive the nature, relevance, and impact of their firm's sustainability activities?

Corporate sustainability is a complex concept and refers to the practice of enhancing ecological, social, and economic goals to meet the needs of both current and future generations [9-14]. The rising prominence of sustainability discourse is arguably due to the deteriorating trends of sustainability-related problems, including global warming, child labor, accelerated loss of biodiversity, increasing levels of pollution, health and safety issues, as well as increasing income inequality [15]. Organizations are normally blamed as the originators and facilitators of these problems with the expectations for managers of organizations to help deal with sustainability issues [5]. Sustainability initiatives are thus perceived, planned, and executed by managers of organizations, yet academics have acknowledged that little is known about how managers of firms perceive the nature, relevance, and impact of sustainability activities [5].

This issue is explored in the context of firms operating in Croatia, employing multiple theoretical concepts and utilizing a qualitative methodological research approach. Although limited sustainability-related studies exist in the context of the transitional region of Central and Eastern Europe (CEEC) [16-18], those that do exist tend to be mainly conceptual and discussion-based papers [19-21]. However, this study is based on twenty-five interviews with both current and former managers of eighteen companies. These firms range from small and medium size enterprises (SMEs) to multinational corporations (MNCs) operating in Croatia. Croatia is one of the Eastern European countries that has experienced substantial economic growth after joining the European Union and has undergone a tremendous social change in the last two decades. Sustainability issues are still emerging in this context, with managerial views and decisions shaping the nature of sustainability issues in organizations. The study contributes to the sustainability literature in a number of ways. Firstly, by investigating managerial perceptions, it highlights the challenges and practicalities that managers must consider in addressing sustainability issues. Secondly, it contributes to the literature by identifying three distinct levels of sustainability commitments by firms, including minimal response, corporate culture-driven response and committed response. Thirdly, the findings enrich and extend the prior application of legitimacy theory to understand managerial perceptions on sustainability issues.

The remainder of this paper is organized into five sections. The next section provides the literature review consisting of an abbreviated theoretical foundation and a review of empirical studies. The research methodology is next discussed and the results are presented. To close the paper, research conclusions are drawn and the limitations of the project and managerial implications considered.

\section{Literature Review}

Several literature reviews on sustainability have appeared in the last decade [22-25] and most of the emphasis in these articles has been on academic work (both theoretical and empirical) focusing on the dimensions and importance of sustainability activities and how they impact corporate performance [26-28]. There are varying assumptions about the sustainability concept due to its complex character and multi-domain nature [29]. Corporate sustainability as a complex concept deals with a variety of economic, social, and environmental objectives and demands organizational and societal levels that are connected and interdependent but appear desirable in isolation [30]. Accordingly, corporate sustainability confronts managers with complex tensions between environmental, economic, and social aspects, which require managerial judgments and perceptions to effectively navigate through the ambiguous decision-making contexts presented by the multitude of sustainability issues [30]. Therefore, sustainability increasingly requires corporate decision-makers to consider and address the interconnected and diverging economic, environmental and social concerns [30].

Traditionally, the dominant theme of sustainability domains, which include the economic, social, and environmental, focuses on the trade-offs between them [31]. The emergence and application of the 
triple-bottom-line (TBL) framework in more recent research recognizes the interdependence of these domains [29]. This has been further underpinned by the paradox perspective, which views the various dimensions of sustainability as divergent and competing demands resulting in tension in sustainability management [32]. This interdependence is further observed by other researchers as dynamic due to the interaction of external social, political, and economic influences [32]. Sustainability is consequently considered an integrative perspective with regard to the embeddedness of both firms and managers in the broader context [29].

Drawing on managerial cognition, studies have identified managerial sensemaking as an adequate guide in managing the simultaneous achievement of social, economic, and environmental objectives [30]. Hahn et al. [30], for instance, proposed a business and paradoxical frame that managers adopt to address sustainability issues. The two frames occupy the extreme ends of a cognitive framing continuum based on contrasting views of the economic, social, and environmental dimensions, the relationship between them, and the impact of managerial decision making on sustainability issues [30]. They posit that managers with cognitive frames underpinned by the business case tend to selectively pursue narrow but workable environmental and social issues that align with the economic aspirations of the firm [11]. Managers with the business case cognitive frame interpret the impact of sustainability issues for their business only as either positive or negative. On the other hand, managers with paradoxical frames consider the multiple and conflicting environmental, social, and economic issues extensively in developing more comprehensive solutions which are then carefully and slowly implemented.

Others note that the arguments on why and how firms deal with sustainability are dominated by the legitimacy-seeking and profit-seeking perspectives [33,34]. The profit-seeking argument suggests that sustainability activities are planned and implemented by organizations in order to further their economic performance [5]. Accordingly, managers as agents for the owners of the business have the main responsibility for their companies' economic success. In this regard, managers would initiate sustainability activities that would strengthen their financial position. Arguably, the implementation of the sustainability initiatives will be done in such a way as to create financial advantages that would support the bottom line of the firm. This perspective emphasizes that the only responsibility for firms is to maximize profit, but within the laws and regulations, devoid of fraud or deception, and through open and free competition. Another argument supporting the profit-seeking perspective is the business case for sustainability, which suggests that firms engage in sustainability activities in order to exploit the economic opportunities related to them [35]. Thus, managers would use instrumental cost and benefit analysis to frame social and environmental issues [5].

The legitimacy-seeking view, on the other hand, suggests that organizations design and implement sustainability activities in order to strengthen the appropriateness and approval of their operations by stakeholders [2]. Sustainability activities enable firms to gain and sustain the license to operate within the society, and this helps the firm to maximize its corporate image as well as other benefits $[26,36]$. The main premise of the legitimacy-based view is the need for firms to engage and comply with stakeholder pressure and manage any conflicting stakeholder pressure to gain approval [2,5]. The legitimacy of an organization's activities in the eyes of stakeholders would arguably translate to lower risk, survival, long-term sustainability, and continuous operation [1]. This perspective is underpinned by the institutional theory, which emphasizes the importance of institutions and institutional structures in the organizations' operations and structures [5]. Institutions emerge from the firms' environment and comprise of the set of rules, beliefs, norms, values, and regulations in society established by stakeholders and within which firms operate [37,38]. Scholars have highlighted the importance of institutional pressures in shaping firms' sustainability practices and in exerting normative, regulative, and cognitive influence over the firm $[39,40]$. Moreover, the inadequacy or otherwise of the interlocking formal and informal institutions constrain firms or enable firms to accommodate and foster the coexistence and management of the conflicting economic, environmental, and social sustainable objectives [21,41].

Aligned to the legitimacy and institutional theories is the stakeholder perspective proposed by Freeman [42] and delineated [43] as falling into four categories, including organizational 
(employees, customers, suppliers, and shareholders), community (local residents and special interest groups), regulatory (government at national and local levels), and media (traditional and online). Stakeholder theory has also been used as a theoretical underpinning for much of the earlier sustainability literature $[25,28,44-48]$. In early work on transitional economies, one author noted that sustainability "should be understood as corporate responsibility to stakeholders, rather than as corporate philanthropy, public relations, or marketing and that limitations associated with corporate responsibility in CEEC are associated with limitations in stakeholder responsibility" [42].

Studies have begun to examine the dimensions of sustainability employed in order to achieve profit-seeking objectives or legitimacy seeking objectives [2]. According to Zheng et al. [2], firms use compliance and strategic adaptation as strategies to achieve legitimation. Compliance involves the active response to stakeholders' explicit demands in order to reduce any potential negative consequences of non-compliance. Strategic adaptation, on the other hand, focuses on the design and the emphasis of a particular form of sustainability beyond what is required by compliance-threshold behavior. Zheng et al. [2] adopted philanthropy and sustainability as two extreme and important strategies to achieve legitimacy. Sustainability, in their view, requires the integration of social and environmental issues into the core business operations and may necessitate modification or replacement of the business model [2]. We examine how managers perceive the nature, relevance, and impact of their firms' sustainability activities.

\section{Methodology}

\subsection{Research Design, Research Setting and Sampling}

Given the lack of research on former employees' perceptions of sustainability, as well as the limited empirical literature on managers' perceptions of sustainability, a research design has been adopted to include detailed qualitative investigations. This approach is ideal for understanding and unraveling the complexities involved in managerial perceptions of sustainability [28,49]. Indeed, the qualitative approach has been found to be appropriate in studying unexplored and complex issues based on perceptions, beliefs, and values of respondents [50,51]. A grounded theory approach is used since the objective is to unravel the perceptions underlying sustainability practices and to address questions around the adequacy of any previous conceptualizations of sustainability [4]. This requires collection of rich and in-depth data, and as such, in-depth interviews, analysis of field notes, and content analysis of information from corporate websites and CSR reports are appropriate approaches for this research.

In order to further enhance and develop an understanding of sustainability perceptions, this study is focused on managers and former managers of companies with different levels of sustainability engagement, commitment, and divergent strategies [52]. This approach was adopted in order to reduce potential bias and ensure varied responses. Former managers or outside employees are seen as providing more independent judgments because there is no potential for conflict of interest, which may affect the judgments of inside managers $[53,54]$. The respondents interviewed were identified through multiple methods including a direct approach, networking and snowballing, which have been identified to be particularly effective in collecting data in transition economies and institutional environments [50]. To identify firms with sustainability initiatives across all industries for inclusion in the study, we first read and content-analyzed firms' websites and news reporting techniques. All industries were considered since sustainability issues apply to all industries. We identified approximately 35 firms to contact for the purpose of the interview. After directly approaching these firms, 15 agreed to participate in the study. A further three companies and six former managers were identified through networking and snowballing. The final group of respondents comprised of 19 current managers and six previous managers, from 18 companies, spanning 14 different industries, including retail, food and beverage, gaming, oil and gas, organic food, pharmaceutical, fast moving consumer goods (FMCG), banking and finance, media, professional consulting, PR, construction, utilities (electricity), and sanitary fitting provider. See Table 1 for sample descriptions. 
Croatia, the selected country for the research context, joined the European Union (EU) as a member state in 2013. Notwithstanding, it is classified as a transition economy with significant differences from other EU members in terms of economic growth, business environment, management practices, and income levels. Moreover, Croatia has a challenging political, environmental, social, and economic past, which still influences current practices in its organizations. Croatia's economic development, as well as its political and social environments, are, therefore, quite different from its EU counterparts. Therefore, examining managerial perceptions of sustainability issues in Croatia would likely yield unique and impactful outcomes.

Table 1. Description of participants.

\begin{tabular}{|c|c|c|c|c|c|}
\hline No. & Gender & Age & Position & Industry & Education \\
\hline \multicolumn{6}{|c|}{ Current Managers } \\
\hline 1 & $\mathrm{~F}$ & 50 & Category manager & Retail & MBA degree \\
\hline 2 & $\mathrm{~F}$ & 55 & Director of R\&D Department & Food and Beverage & PhD degree \\
\hline 3 & $\mathrm{~F}$ & 59 & Head of Marketing Department & Gaming & BA degree \\
\hline 4 & $\mathrm{~F}$ & 48 & $\begin{array}{c}\text { Head of Corporate Service } \\
\text { Department }\end{array}$ & Oil and Gas & MBA degree \\
\hline 5 & $\mathrm{~F}$ & 54 & $\mathrm{CEO}$ & Organic food & MBA degree \\
\hline 6 & M & 35 & Director of Retail Department & $\begin{array}{c}\text { Provider of sanitary } \\
\text { fittings }\end{array}$ & PhD degree \\
\hline 7 & $\mathrm{M}$ & 36 & Retail manager & Pharmaceutical & BA degree \\
\hline 8 & M & 32 & Brand manager & FMCG & BA degree \\
\hline 9 & $\mathrm{~F}$ & 38 & Retail manager & Drugstore chain & BA degree \\
\hline 10 & M & 39 & Retail representative & Insurance & BA degree \\
\hline 11 & $\mathrm{~F}$ & 36 & Marketing manager & Banking and Finance & BA degree \\
\hline 12 & $\mathrm{~F}$ & 34 & Marketing manager & Pharmaceutical & BA degree \\
\hline 13 & $\mathrm{~F}$ & 45 & Marketing manager & $\begin{array}{l}\text { Media/Professional } \\
\text { Consultancy/PR }\end{array}$ & MBA degree \\
\hline 14 & M & 50 & $\mathrm{CEO}$ & Construction & BA degree \\
\hline 15 & $\mathrm{~F}$ & 48 & Marketing manager & Food and Beverage & MBA degree \\
\hline 16 & $\mathrm{~F}$ & 40 & CEO & Automotive & BA degree \\
\hline 17 & $\mathrm{~F}$ & 42 & Director & Cleaning services & BA degree \\
\hline 18 & M & 50 & CEO & International Airport & BA degree \\
\hline 19 & $\mathrm{~F}$ & 36 & Marketing manager & Publishing & BA degree \\
\hline \multicolumn{6}{|c|}{ Prior Managers } \\
\hline 20 & $\mathrm{~F}$ & 50 & Consultant & Retail & BA degree \\
\hline 21 & $\mathrm{~F}$ & 43 & PR manager & Food \& Beverage & BA degree \\
\hline 22 & $\mathrm{~F}$ & 62 & Consultant & Gaming & BA degree \\
\hline 23 & $\mathrm{~F}$ & 49 & Finance manager & Oil and Gas & MBA degree \\
\hline 24 & M & 26 & Brand manager & FMCG & Masters degree \\
\hline 25 & $\mathrm{~F}$ & 32 & HR Manager & Drugstore chain & BA degree \\
\hline
\end{tabular}

\subsection{Data Collection}

Access to company managers was negotiated with the respective companies' higher management. Anonymity was assured in order to encourage open and detailed answers as well as access to other data. Previous company managers were directly contacted through phone or email and were likewise 
assured of anonymity. The in-depth interviews were conducted with managers over a twelve-month period. The interview protocol was developed in line with Öberseder and Murphy [28], who had used a similar approach and found it appropriate. Interview guidelines were pre-tested [55]. One crucial factor in the success of the interviews was the development and implementation of a strict agreement for ensuring the anonymity of individual participants and the specific companies they represent [56].

The purpose of the interviews was to identify current and former managers' perceptions around the nature, significance, and impact of sustainability practices in their organizations. Before the data collection commenced, an initial interview guide was drafted in English and then translated into Croatian. The Croatian version was then independently back-translated and compared against the original one. As a result, minor modifications were made to ensure linguistic comparability. The questions asked during the interviews were based on four main themes, their understanding and scope of sustainability activities, the nature and relevance of sustainability in their firm, employee perceptions of sustainability, and other stakeholder perceptions of their sustainability activities. Interviews lasted from fifty minutes to two hours. At the beginning of the interview, most managers were delighted to discuss sustainability in the sense of "look how great we are", but as time passed and interviews became more relaxed, managers gave more reflective and critical comments about their firm's sustainability activities. Almost all of the interviews were recorded, transcribed and translated into English for analysis. The quotes that appear in the paper were carefully translated into English (and back-translated) multiple times to best capture the managers' "voices" [56].

\subsection{Data Analysis}

In our data analysis, we adopted the approach outlined by Miles and Huberman [57]. The recorded interviews were transcribed verbatim, and where the informants objected to being recorded, field notes were taken in those cases. Under these circumstances, the "24-hour rule" was adopted to help ensure an accurate chronology of events and to "capitalize on the immediacy of the data" ([58], p. 374). Field notes were transcribed and the chronology of events logged immediately after each interview. In cases where field notes were taken, they were checked by the respective interviewee to confirm that accurate representation of their views were maintained. Moreover, the information obtained via corporate websites and reports were also content analyzed alongside the primary data.

The data were analyzed using a thematic analysis technique, where the transcripts are examined in order to identify patterns of meaning and emergent themes [16]. Data analysis, therefore, began with a detailed coding of the transcripts. Through this process, a number of categories and common themes became increasingly salient. These themes centered on a number of areas: (1) The scope of sustainability activities, (2) stakeholder domains, and (3) stages of sustainability commitment. Since the primary data collection was completed by one of the authors, the co-authors who were not part of the primary data collection process were tasked with critically examining and challenging the resulting codes and categorizations [24]. This triangulation was performed to help increase validity and ensure confidence in the data [59]. We present the results of our analysis in the following section and use quotations to examine the theoretical constructs and to bring clarity to the emergent themes.

\section{Findings}

This section presents the findings from our interviews with managers of firms in Croatia about sustainability. The first part deals with general impressions about sustainability activities by firms, as provided by the respondents. The second part of this section deals with the results regarding the broader sustainability activities by firms in Croatia. The section part concludes with a classification of the sustainability stages in Croatian companies.

\subsection{Nature and Relevance of Sustainability}

The analysis reveals that corporate sustainability is an emerging concept. It further showed that sustainability activities are primarily focused on environmental protection, investment in community 
partnerships, and in enhancing the bottom lines of firms. However, managers perceive sustainable initiatives necessary for businesses in the research context. Sustainability has become a relevant requirement for gaining legitimacy and improving the success of the business. Respondents observed that sustainability has emerged in response to the increasing awareness of the role of business in society and the environment, with respect to the protection of stakeholders and the environment. Regarding the centrality of sustainability in organizations, a respondent stated that:

"... the purpose of the existence of a company is to positively affect the environment in which it operates... sustainability is something that we cannot take for granted and something that should be based on the existence of each company. Sustainability in our company, in fact, reflects only what we are basically trying to do: to have ... transparent business and thereby safeguard human health and the environment." (Organic food company).

The analysis further shows that sustainability practices in Croatia focusing on environmental protection, in particular, is increasing due to a number of external factors, such as tougher legislation, the maturation of consumer and public awareness, the lack of non-renewable sources of energy, decreasing raw material resources and increasing costs. In particular, companies engaging in activities that could affect the natural environment feel responsible for protecting the natural environment. For instance, some respondents revealed that:

"The goal of our company is to increase the use of renewable energy sources in the interest of the rational use of energy resources and reduce greenhouse gas emissions, joining environmental remediation obligations resulting from past operations, to promote the development of a proactive culture in the field of health, safety, and environment." (Electric company).

"We are trying in all our branches to use organic detergents, to recycle, to compost, to save energy ...

" (Organic food company).

Furthermore, our data revealed that the business case perspective predominantly underpins sustainability activities among organizations in this research context. As such, almost all respondents indicated that sustainability principles and practices enable them to gain legitimacy from society and therefore enhance their business performance. The managers interviewed further identified that top executives in the respective firms perceive sustainability more as a way of promoting their own interests, i.e., to increase sales, rather than stemming from a real desire to positively impact the community or the environment. Notwithstanding, respondents revealed that the ideal sustainability activity would be when:

"Sustainability supports profitability" (e.g., implementation of money-saving technologies) and "when promotion of their own products and technology solutions is associated with sustainability" (Electricity company).

Moreover, former managers of the sampled companies were concerned about the implementation of sustainability in their former employment. In their view, sustainability-related activities existed, but much more needs to be done beyond the current trend of firms using philanthropic activities to glorify themselves as sustainable and responsible while their activities at the same time create problems for society, or are just a marketing/PR initiative. For instance, a respondent stated:

"What I think is the most neglected is the awareness of enterprises about their product or service ... you can give your best to help children, but if your product can be harmful to the environment, society and the individual who consumes it ... then the primary task of companies should be to try to reduce the possible harmful consequences and make it less harmful." (Gaming company).

Another respondent revealed that: 
"Sustainability should be implemented in real life and really be accountable to employees, unions, and the local community ... only in that case do you have integrity as a company." (Oil and gas company).

\subsection{Challenges Impeding Sustainability Development}

Respondents further revealed that the lack of an appropriate legal framework to guide firms' sustainability activities is impeding the development of appropriate and extensive sustainability initiatives. The biggest strategic challenge for the majority of companies is to survive in the market, and because there is no legal pressure to deal with sustainability issues, most of them selectively pursue initiatives that support their profitability. Respondents, therefore, bemoan the lack of government pressure as the biggest obstacle to enhancing sustainability activities in firms. In line with this, it became evident that the increasing introduction of regulations and other institutions with respect to environmental protection has begun to foster the uptake of sustainability activities for companies in the research context. This is particularly so in certain key industries that are perceived as more likely to impact the natural environment, such as oil and gas, agriculture, electric and electronic, car manufacturing sectors. An interviewee remarked that:

"I think that our most important activity that surpasses legal regulations is the production of renewable energy sources via photovoltaic cells as an important example of environment protection." (Car dealer).

The results further demonstrate that sustainability in Croatia suffers due to active regulatory and supervisory bodies who control the production and consumption of certain products and services. Moreover, the data suggested that government agencies are often not willing to ensure basic standards with regards to regulatory measures within the marketplace are complied with in order to protect consumers. One manager from a private company was happy to point out that everything they do is above the law, while another's view was that the government should be much more engaged in the implementation and control of CSR.

"The ministry is very non-transparent, they cooperate with some companies, criteria are not clear when they are giving patronage to an action ... supervision and regulation on 'top' is the most important because it can have dramatic consequences for the wider environment and society. However, it should depend on the strategy of the state, for example, the situation in our country. We build coal-fired plants, which the whole world is abandoning. At the same time, we want to boost agriculture and tourism as totally opposite things, and that only shows that the government has no clear strategy." (Organic food company).

Respondents further emphasize that the government should stimulate sustainability initiatives and be a more active partner in the sustainability actions of firms. Currently, companies are primarily engaged to an extent that just manages to meet basic economic and legal expectations. They make money for owners, pay taxes, and operate within relevant rules. However, corporations should transition from a state of mere compliance of regulations to a model of proactive engagement, from harm minimization to value creation [60].

This section has, therefore, unpacked firms' increasing uptake of sustainability activities, particularly with regards to environmental protection, enhancing societal needs and economic benefits [1,61]. It highlights the importance of the business case for sustainability activities in this research context. Sustainability activities are predominantly initiated and implemented to help enhance firms' economic success. This section has further signaled how institutional inadequacy is hampering the effective development and deployment of sustainability activities. Moreover, our analysis has not emphasized the importance of balancing the integration of ecological, economic, and social dimensions in organizations' designs and implementation of sustainability activities. 


\subsection{Levels of Sustainability Initiatives}

Through our analysis, we unpacked three different levels of sustainability commitment among organizations in the research context. These levels include a minimal response to sustainability, an adequate and culture-driven response to sustainability, and a committed response. We briefly discuss each of these levels below.

\section{Stage 1: Minimal Response to Sustainability}

The majority of the respondents felt their companies have no or only a minor obligation to sustainability and have not appointed full-time members of staff for initiating and managing sustainability issues. These initiatives largely come from the top management in most of the organizations as a minimal response to stakeholder complaints or legal requirement. With regard to implementing sustainability initiatives, most attention is given to those that are required by law or that strengthen short-term strategic objectives. It was clear from our dataset that the motive for engaging in sustainability activities was largely to gain competitive advantage and improve the financial performance of companies. Companies at this level of development tended to primarily focus on initiatives that had the potential to attract the attention and approval from customers, employees, and shareholders because profitability is directly dependent upon them. Our analysis further revealed that these companies do not have sustainability activities that go beyond legal requirements. The following statement from a respondent was typical:

"The budget for sustainability activities has been reduced due to economic crises." (Food company).

Former managers of these companies, however, described sustainability activities in their previous organizations as minimal and aimed at following the trend. Accordingly, corporations have some guidelines that look impressive on paper but do not translate to actual actions implemented. Some of the former managers remarked about their former employers' sustainability actions as:

"They emphasize care of employees as one of the most important elements ... but realistically when you are in that system, you see that is not even close to that level where they declare it." (Retail company).

"When I look at my former company and their sustainability activities, I see only some prize games... This is not near to sustainability. For me, it should be to help the community and abandoned children. All they do is eventually to present some prize competition at the petrol station to the final consumer who already paid the high price of fuel." (Oil and gas company).

A company at this minimal response level of corporate sustainability development does not truly engage in sustainability activities on a day-to-day basis, and runs the risk of being accused of using it as exclusively for PR purposes [24]. The practices in these firms lack a systematic, focused, and institutionalized approach to sustainability [59].

\section{Stage 2: Corporate Culture-Driven Sustainability}

This stage is where companies are interested in implementing substantial sustainability initiatives, but still face serious obstacles. As in level 1, stage 2 firms also do not have bespoke departments for sustainability, but do have a longstanding commitment to initiating and implementing sustainability activities. Such activities are intertwined in HR, PR, quality management and marketing. Some of them provide sustainability reports on the basis of the Global Reporting Initiative (GRI) guidelines. They engage in open dialogue with several stakeholders and encourage the adoption and implementation of sustainability. Their long-term goals are the improvement of existing activities and the introduction of new features and contents in sustainability projects. This is captured by the responses of two managers as follows: 
"Our beginning of sustainability goes back to about 30-40 years ago, and real structured sustainability comes around 2005 with the change of management. We are a German company and it is logical that we insist on sustainability. As you go east, there is less concern about sustainability." (Waste services).

"With sustainability activities, we systematically began 20 years ago ... it's just a commonsense way, necessary for a successful business ... all we do is above the law, there are no legal provisions that lead us to this behavior ... sustainability works best when there is the commitment of top management." (Construction company).

Companies at this level are still developing their sustainability programs and initiatives. In addition, these companies play by the "rules of the game" [59] but also follow and fulfill all legal requirements regarding sustainability. The role of top management is key in initiating and implementing effective sustainability activities, as well as integrating them into the culture of the firm. Steurer and Konrad [62] suggested that sustainability requires a more systematic approach.

Stage 3: Sustainability as a Committed Response

The final level of companies' response to sustainability in the research context is a committed response. Companies' business philosophy, at this level, implies responsible and sustainable behavior. They are likely to have many sustainability activities that go beyond legal requirements and sustainable activities are passionately pursued. Moreover, at this level, such companies take the responsibility of engaging with their stakeholders very seriously. In our study, only two companies fell into this category. The first firm's focus derived both from its mission and employees, and the second firm's success is as a result of respecting employees and customers first and foremost. A manager revealed that:

"At the beginning of our business, we also started with sustainability activities although we didn't declare it. To be clear, our philosophy of life implies that behavior like that is very important, so we do not know otherwise. We believe in that to the extent that it should not stand out too much. A lot of our sustainability activities are beyond legal requirements, because we made sustainability activities based on our own inspiration and beliefs and not only because they are required by law. Ideas for sustainability are coming from the management to the business units, but also from the employees, so we adopt and implement them. Our sustainability activities are successful because they are done with passion." (Organic food company).

Another respondent narrated that:

"When we arrived in Croatia and when someone mentioned sustainability, people would ask what is it ... and today we are launching a trend. We are turning toward ecology and campaigns for a healthy life. We are putting focus on the development of our employees and customers. Even within this economic crisis, we have increased our spending on sustainability activities." (Drugstore chain).

These companies put sustainability at the core of the business practice and outperform many of their competitors with regards to sustainability. Sustainability as a committed response is when it is rooted in people-centeredness, environmental protection, ethical principles, and human rights commitments [63,64].

\section{Discussion and Conclusions}

Although nascent research on corporate sustainability is increasing, a number of scholars have begun to highlight the potential importance of managerial perceptions in planning and implementing sustainability initiatives $[4,6,7]$. There is only limited research on how managers perceive the nature and relevance of their sustainability activities [5]. Our main aim in this study has been to contribute to developing and consolidating this emerging body of research, by turning our attention to the role of managerial perceptions in companies' sustainability activities. We, therefore, examined in 
this study how managers perceive the nature, relevance, and impact of their firms' sustainability activities. Our analysis shows that managers perceive sustainability initiatives as a tool for gaining legitimacy and profit maximization. Sustainability issues are predominantly aligned to the business case perspective, and not well-integrated into the core business strategies of firms or held in equal balance with economic returns [11]. However, the emerging sustainability practices in organizations within the research context tend to focus on environmental protection, investment in community partnerships, and supplier and consumer satisfaction. Moreover, the data reveal a lack and inadequacy of regulatory frameworks on sustainability in the research context which is discouraging the uptake and committed response to sustainability initiatives. The findings of our study have a number of theoretical and practical implications.

\subsection{Theoretical Implications}

Our study makes three sets of contributions. First, we developed a three-stage model of sustainability practices based on managerial perceptions. The first stage is where managers perceive and implement sustainability activities as a minimal response. At this stage, the primary focus of the firm is to gain legitimacy, competitive advantage, and superior financial performance through sustainability activities. Moreover, sustainability activities at this stage tend to lack a systematic, focused, and institutionalized approach in the organizations, but rather within legal requirements [59]. Companies operating at this level of sustainability tend to use such activities predominantly for public relations and marketing purposes [24]. The majority of firms in our sample operate at this level of sustainability. The second component of the three-stage model developed in our analysis is the stage where sustainability is driven into the company's culture. Companies at this stage have a longstanding sustainability-driven culture with a long-term orientation. However, these organizations do not have dedicated divisions with resource allocations to ensure effective execution of sustainability initiatives. The third and final stage of the model is the level of committed sustainability response where sustainable behavior is intrinsic and naturally inherent in the business philosophy. Examples of sustainability activities at this level are people-centeredness, and more orientation towards environmental protection, ethical principles, and human rights commitments [63,64]. Our analysis revealed that only two companies in our sample were operating at this level of sustainability.

By investigating managerial perceptions, our study highlights the challenges and practicalities that managers must consider in addressing sustainability issues. In particular, the study enriches and extends the prior application of the legitimacy theoretical lens to understand managerial perceptions of sustainability issues. It is clear from our research that the major obstacles to successful sustainability implementation in Croatia are low awareness and weak interest in sustainability issues by stakeholders. The Croatian market has not yet advanced to the point where sustainability has the same emphasis as in developed European countries (e.g., Nordic countries, UK, France, and Austria). Examples taken from these countries could stimulate cross-border learning. The findings confirm the same lack of systematic, focused, and institutionalized approach to sustainability in this research context, as identified in other research contexts [59]. Moreover, the study enriches the applicability of the institutional theoretical perspective on sustainability studies. Finally, it adds to the limited micro-level sustainability practices and mechanisms in transition economies [39].

A further contribution to the literature can be drawn from the divergent perceptions of sustainability activities from current and previous managers. Current managers seemed to be satisfied with the present level of sustainability initiatives in their organizations and, in fact, praised actions undertaken on behalf of a particular group of stakeholders. Former managers, on the other hand, were more skeptical about the genuine nature of such initiatives by their former organizations. They reflected on sustainability issues in a more factual manner, concluding that sustainability in Croatia is more marginal, short-term oriented, and undertaken primarily for the realization of higher income. Perceptions between the current and former managers were considerably different in most of the domains. 
The next insight drawn from the study, is that whilst Central and Eastern Europe (CEE) has historically been identified as a good setting for the development of sustainability activities, there is a lack of stakeholder activity in CEE. The results of this study did show a modest effort to focus on stakeholders within the sampled companies and the level of sustainability awareness seems to be growing. However, just two companies were strongly committed to sustainability, differing from all other respondents by looking beyond narrow economic returns to include the wider social concerns into consideration [65].

\subsection{Practical Implications for Managers}

This study brings about a number of important implications for managers and companies in the development and implementation of their sustainability activities. One implication for managers is that sustainability is becoming a more strategic and recognized activity in the transition country of Croatia. Although managers place more emphasis on the customer, employee, and environmental domains as the most relevant stakeholders in their sustainability activities, this study highlights the importance of managers in engaging with other stakeholders, such as suppliers. Moreover, organizations that are the first movers in positioning sustainability as more strategic and integral to their corporate agenda would benefit by having the advantages of extensive market knowledge and innovative ways of implementing sustainability. Additionally, the presence of global companies in Croatia is likely to stimulate local firms to engage in similar strategic sustainability activities in order to keep pace with competitors.

By demonstrating the critical views of former managers on the sustainability activities within their former organizations as short-term focused and lacking strong ethical considerations, this study has again shed light on other important aspects of activities that firms can consider in order to augment their sustainability activities. On a pragmatic level, firms might consider discussing sustainability activities in exit interviews. The study also highlights the fact that ethical matters should be taken into consideration in the planning and implementation of sustainability activities. In addition, as markets mature, broader, more effective, and larger-scale sustainability activities are likely to emerge, and firms should keep pace with such developments. Finally, studies such as this are important benchmarks for managers to judge their own sustainability initiatives, and influence future initiatives, both in Croatia and in other transitional economies.

\section{Limitations and Future Research}

Despite its contributions, this study is constrained by some limitations that can be taken into account in future projects in order to enhance the robustness of the findings. One potential limitation is non-generalizability of qualitative data [66]. The generalizability of the findings could be enhanced by developing a measurement tool for sustainability domains to empirically test these domains through surveys rather than in-depth interviews. For broad-ranging qualitative work, more interviews spanning multiple countries could be carried out and possible comparisons made to enhance the generalizability of the findings. Furthermore, future studies could investigate the perceptions of other important stakeholders, such as consumers, employees, and suppliers with regards to their organizations' sustainability actions. Consumers might be asked to compare the efforts of multiple companies across multiple sectors with regards to sustainability activities and responsiveness to consumer concerns.

Another potential research project which could extend this study is the consideration of the role of formal and informal institutions in sustainable activities, such as government regulations and local/national cultural trends and movements that may facilitate or impede the nature and type of sustainability activities developed and implemented by firms. Finally, such research may yield further insights into the role of foreign firms in facilitating the implementation of sustainability activities by domestic firms. 
Author Contributions: Conceptualization, R.N.; Data curation, R.B.; Formal analysis, R.N.; Methodology, R.B.; Supervision, P.M.; Validation, P.M.; Writing—original draft, R.N., R.B. and P.M.; Writing-review \& editing, R.N., R.B. and P.M. All authors have read and agreed to the published version of the manuscript.

Funding: This paper is based on research undertaken as part of Horizon 2020 Project Strength2Food (No.678024).

Conflicts of Interest: The authors declare no conflicts of interest.

\section{References}

1. Burritt, R.L.; Christ, K.L.; Rammal, H.G.; Schaltegger, S. Multinational enterprise strategies for addressing sustainability: The need for consolidation. J. Bus. Eth. 2018, 1-22. [CrossRef]

2. Zheng, Q.; Luo, Y.; Maksimov, V. Achieving legitimacy through corporate social responsibility: The case of emerging economy firms. J. World Bus. 2015, 50, 389-403. [CrossRef]

3. Topalli, M.; Ivanaj, S. Mapping the evolution of the impact of economic transition on Central and Eastern European enterprises: A co-word analysis. J. World Bus. 2016, 51, 744-759. [CrossRef]

4. Fassin, Y.; Van Rossem, A.; Buelens, M. Small-business owner-managers' perceptions of business ethics and CSR-related concepts. J. Bus. Eth. 2011, 98, 425-453. [CrossRef]

5. Schaltegger, S.; Burritt, R. Business cases and corporate engagement with sustainability: Differentiating ethical motivations. J. Bus. Eth. 2018, 147, 241-259. [CrossRef]

6. Cacioppe, R.; Forster, N.; Fox, M. A survey of managers' perceptions of corporate ethics and social responsibility and actions that may affect companies' success. J. Bus. Eth. 2008, 82, 681-700. [CrossRef]

7. Das, T.K. Managerial perceptions and the essence of the managerial world: What is an interloper business executive to make of the academic-researcher perceptions of managers? Br. J. Manag. 2003, 14, $23-32$. [CrossRef]

8. Murphy, P.E.; Öberseder, M.; Laczniak, G.R. Corporate societal responsibility in marketing: Normatively broadening the concept. AMS Rev. 2013, 3, 86-102. [CrossRef]

9. Bansal, P.; Song, H.C. Similar but not the same: Differentiating corporate sustainability from corporate responsibility. Acad. Manag. Ann. 2017, 11, 105-149. [CrossRef]

10. Gao, J.; Bansal, P. Instrumental and integrative logics in business sustainability. J. Bus. Eth. 2013, 112, $241-255$. [CrossRef]

11. Hahn, T.; Pinkse, J.; Preuss, L.; Figge, F. Tensions in corporate sustainability: Towards an integrative framework. J. Bus. Eth. 2015, 127, 297-316. [CrossRef]

12. Rhoades, L.; Eisenberger, R.; Armeli, S. Affective commitment to the organization: The contribution of perceived organizational support. J. Appl. Psychol. 2001, 86, 825-836. [CrossRef]

13. Van Marrewijk, M.; Werre, M. Multiple levels of corporate sustainability. J. Bus. Eth. 2003, 44, 107-119. [CrossRef]

14. Yin, J.; Jamali, D. Strategic corporate social responsibility of multinational companies subsidiaries in emerging markets: Evidence from China. Long Range Plan. 2016, 49, 541-558. [CrossRef]

15. McShane, L.; Cunningham, P. To thine own self be true? Employees' judgments of the authenticity of their organization's corporate social responsibility program. J. Bus. Eth. 2012, 108, 81-100. [CrossRef]

16. Boyatzis, R.E. Transforming Qualitative Information: Thematic Analysis and Code Development; Sage Publications: London, UK, 1998.

17. Stoian, C.; Zaharia, R.M. Corporate social responsibility in Romania: Trends, drivers, challenges and opportunities. Int. J. Econ. Bus. Res. 2009, 1, 422-437. [CrossRef]

18. Stoian, C.; Zaharia, R.M. CSR development in post-communist economies: Employees' expectations regarding corporate socially responsible behaviour-the case of Romania. Bus. Eth. A Eur. Rev. 2012, 21, 380-401. [CrossRef]

19. Debeljak, J.; Krkac, K.; Banks, I.B. Acquiring CSR practices: From deception to authenticity. Soc. Responsib. J. 2011, 7, 5-22. [CrossRef]

20. Stubbs, P.; Kennedy, T.J.; Vlahović, M.T.; Sachsa, M.; Redžepagić, D. Creating sustainability competences through reporting in Croatia. In Proceedings of the 7th International Conference on Enterprise in Transition, Bol, Croatia, 24-26 May 2007; pp. 1-21. Available online: http://paulstubbs.pbworks.com/f/Stubbs+Tafra+ Redzepagic+Split.pdf (accessed on 20 May 2014). 
21. Vitezić, N. Corporate reputation and social responsibility: An analysis of large companies in Croatia. Int. Bus. Econ. Res. J. (IBER) 2011, 10, 85-96. [CrossRef]

22. Aguinis, H.; Glavas, A. What we know and don't know about corporate social responsibility a review and research agenda. J. Manag. 2012, 38, 932-968.

23. Carroll, A.B.; Shabana, K.M. The business case for corporate social responsibility: A review of concepts, research and practice. Int. J. Manag. Rev. 2010, 12, 85-105. [CrossRef]

24. Öberseder, M.; Schlegelmilch, B.B.; Murphy, P.E. CSR practices and consumer perceptions. J. Bus. Res. 2013, 66, 1839-1851. [CrossRef]

25. Freeman, R.E. Strategic Management: A Stakeholder Approach; Pitman: Boston, MA, USA, 1984.

26. Du, S.; Bhattacharya, C.B.; Sen, S. Maximizing business returns to corporate social responsibility (CSR): The role of CSR communication. Int. J. Manag. Rev. 2010, 12, 8-19. [CrossRef]

27. Lantos, G.P. The boundaries of strategic corporate social responsibility. J. Consum. Mark. 2001, 18, 595-632. [CrossRef]

28. Nambiar, P.; Chitty, N. Meaning making by managers: Corporate discourse on environment and sustainability in India. J. Bus. Eth. 2014, 123, 493-511. [CrossRef]

29. Miles, M.B.; Huberman, A.M. Drawing valid meaning from qualitative data: Toward a shared craft. Educ. Res. 1984, 13, 20-30. [CrossRef]

30. Hahn, T.; Preuss, L.; Pinkse, J.; Figge, F. Cognitive frames in corporate sustainability: Managerial sensemaking with paradoxical and business case frames. Acad. Manag. Rev. 2014, 39, 463-487. [CrossRef]

31. Gioia, D.A.; Thomas, J.B. Identity, image, and issue interpretation: Sensemaking during strategic change in academia. Adm. Sci. Q. 1996, 41, 370-403. [CrossRef]

32. Hahn, T.; Figge, F.; Pinkse, J.; Preuss, L. A paradox perspective on corporate sustainability: Descriptive, instrumental, and normative aspects. J. Bus. Eth. 2018, 148, 235-248. [CrossRef]

33. Fukukawa, K.; Teramoto, Y. Understanding Japanese CSR: The reflections of managers in the field of global operations. J. Bus. Eth. 2009, 85, 133-146. [CrossRef]

34. Regnér, P.; Edman, J. MNE institutional advantage: How subunits shape, transpose and evade host country institutions. J. Int. Bus. Stud. 2014, 45, 275-302. [CrossRef]

35. Schaltegger, S.; Hörisch, J. In search of the dominant rationale in sustainability management: Legitimacy-or profit-seeking? J. Bus. Eth. 2017, 145, 259-276. [CrossRef]

36. Kourula, A.; Pisani, N.; Kolk, A. Corporate sustainability and inclusive development: Highlights from international business and management research. Curr. Opin. Environ. Sustain. 2017, 24, 14-18. [CrossRef]

37. Jick, T.D. Mixing qualitative and quantitative methods: Triangulation in action. Adm. Sci. Q. 1979, 24, 602-611. [CrossRef]

38. Walker, K.; Zhang, Z.; Ni, N. The Mirror effect: Corporate social responsibility, corporate social irresponsibility and firm performance in coordinated market economies and Liberal market economies. Br. J. Manag. 2019, 30, 151-168. [CrossRef]

39. Buchanan, S.; Marques, J.C. How home country industry associations influence MNE international CSR practices: Evidence from the Canadian mining industry. J. World Bus. 2018, 53, 63-74. [CrossRef]

40. Maignan, I.; Ralston, D.A. Corporate social responsibility in Europe and the US: Insights from businesses' self-presentations. J. Int. Bus. Stud. 2002, 33, 497-514. [CrossRef]

41. Hahn, T.; Figge, F.; Pinkse, J.; Preuss, L. Trade-offs in corporate sustainability: You can't have your cake and eat it. Bus. Strategy Environ. 2010, 19, 217-229. [CrossRef]

42. Elms, H. Corporate (and stakeholder) responsibility in Central and Eastern Europe. Int. J. Emerg. Mark. 2006, 1, 203-211. [CrossRef]

43. Haugh, H.M.; Talwar, A. How do corporations embed sustainability across the organization? Acad. Manag. Learn. Educ. 2010, 9, 384-396. [CrossRef]

44. Cots, E.G. Stakeholder social capital: A new approach to stakeholder theory. Bus. Eth. A Eur. Rev. 2011, 20, 328-341. [CrossRef]

45. Jackson, I.A.N.J.; Nelson, J. Values-driven performance: Seven strategies for delivering profits with principles. Ivey Bus. J. 2004, 69, 1-8.

46. Luetkenhorst, W. Corporate social responsibility and the development agenda. Intereconomics 2004, 39, 157-166. [CrossRef] 
47. Maignan, I.; Ferrell, O.C. Corporate social responsibility and marketing: An integrative framework. J. Acad. Mark. Sci. 2004, 32, 3-19. [CrossRef]

48. Sobczak, A.; Havard, C. Stakeholders' influence on French Unions' CSR strategies. J. Bus. Eth. 2015, 129, 311-324. [CrossRef]

49. Eisenhardt, K.M. Building theories from case study research. Acad. Manag. Rev. 1989, 14, 532-550. [CrossRef]

50. Birkinshaw, J.; Brannen, M.Y.; Tung, R.L. From a distance and generalizable to up close and grounded: Reclaiming a place for qualitative methods in international business research. J. Int. Bus. Stud. 2011, 42, 573-581. [CrossRef]

51. Schaltegger, S.; Lüdeke-Freund, F.; Hansen, E.G. Business cases for sustainability: The role of business model innovation for corporate sustainability. Int. J. Innov. Sustain. Dev. 2012, 6, 95-119. [CrossRef]

52. Creswell, J.W. Qualitative Inquiry E Research Design-Choosing among Five Approaches, 2nd ed.; Sage: California, USA, 2007.

53. Daily, C.M.; Johnson, J.L. Sources of CEO power and firm financial performance: A longitudinal assessment. J. Manag. 1997, 23, 97-117. [CrossRef]

54. Revell, A.; Stokes, D.; Chen, H. Small businesses and the environment: Turning over a new leaf? Bus. Strategy Environ. 2010, 19, 273-288.

55. Marano, V.; Kostova, T. Unpacking the institutional complexity in adoption of CSR practices in multinational enterprises. J. Manag. Stud. 2016, 53, 28-54. [CrossRef]

56. Frynas, J.G.; Yamahaki, C. Corporate social responsibility: Review and roadmap of theoretical perspectives. Bus. Eth. A Eur. Rev. 2016, 25, 258-285. [CrossRef]

57. Meqdadi, O.A.; Johnsen, T.E.; Johnsen, R.E. Power and Diffusion of Sustainability in Supply Networks: Findings from Four In-Depth Case Studies. J. Bus. Eth. 2018, 159, 1089-1110. [CrossRef]

58. Garriga, E.; Melé, D. Corporate social responsibility theories: Mapping the territory. J. Bus. Eth. 2004, 53, 51-71. [CrossRef]

59. Jamali, D. The CSR of MNC subsidiaries in developing countries: Global, local, substantive or diluted? J. Bus. Eth. 2010, 93, 181-200. [CrossRef]

60. Lin-Hi, N.; Müller, K. The CSR bottom line: Preventing corporate social irresponsibility. J. Bus. Res. 2013, 66, 1928-1936. [CrossRef]

61. Kolk, A. The social responsibility of international business: From ethics and the environment to CSR and sustainable development. J. World Bus. 2016, 51, 23-34. [CrossRef]

62. Steurer, R.; Konrad, A. Business-society relations in Central-Eastern and Western Europe: How those who lead in sustainability reporting bridge the gap in corporate (social) responsibility. Scand. J. Manag. 2009, 25, 23-36. [CrossRef]

63. Kuznetsov, A.; Kuznetsova, O.; Warren, R. CSR and the legitimacy of business in transition economies: The case of Russia. Scand. J. Manag. 2009, 25, 37-45. [CrossRef]

64. Laczniak, G.R.; Murphy, P.E. Normative perspectives for ethical and socially responsible marketing. J. Macromark. 2006, 26, 154-177. [CrossRef]

65. Hoang, H.; Antoncic, B. Network-based research in entrepreneurship: A critical review. J. Bus. Ventur. 2003, 18, 165-187. [CrossRef]

66. Sinkovics, R.R.; Penz, E.; Ghauri, P.N. Analysing textual data in international marketing research. Qual. Mark. Res. An Int. J. 2005, 8, 9-38. [CrossRef]

(C) 2019 by the authors. Licensee MDPI, Basel, Switzerland. This article is an open access article distributed under the terms and conditions of the Creative Commons Attribution (CC BY) license (http://creativecommons.org/licenses/by/4.0/). 